\title{
A Simple Zinc-Mediated Method for Selenium Addition to Michael Acceptors
}

\author{
Francesca Giulia Nacca ${ }^{1,2}$, Bonifacio Monti ${ }^{1}{ }^{10}$, Eder João Lenardão ${ }^{3}{ }^{(0)}$, Paul Evans ${ }^{2}$ and \\ Claudio Santi ${ }^{1, *(\mathbb{D})}$ \\ 1 Group of Catalysis, Synthesis and Organic Green Chemistry, Department of Pharmaceutical Sciences \\ University of Perugia Via del Liceo 1, 06123 Perugia, Italy; nacca.francescagiulia@gmail.com (F.G.N.); \\ bonifaciomonti@gmail.com (B.M.) \\ 2 Centre for Synthesis and Chemical Biology, School of Chemistry University College Dublin, \\ Dublin D04, N2E5, Ireland; paul.evans@ucd.ie \\ 3 LASOL-CCQFA, Universidade Federal de Pelotas-UFPel, P.O. Box 354, 96010-900 Pelotas, RS, Brazil; \\ lenardao@ufpel.edu.br \\ * Correspondence: claudio.santi@unipg.it; Tel.: +39075855106
}

Academic Editor: Francesca Marini

Received: 29 March 2020; Accepted: 23 April 2020; Published: 26 April 2020

\begin{abstract}
In this work, we focused our attention on seleno-Michael type reactions. These were performed using zinc-selenolates generated in situ from diphenyl diselenide 1, 1,2-bis(3-phenylpropyl)diselenide 30, and protected selenocystine 31 via an efficient biphasic $\mathrm{Zn} / \mathrm{HCl}$-based reducing system. Alkenes with a variety of electron-withdrawing groups were investigated in order to gauge the scope and limitations of the process. Results demonstrated that the addition to acyclic $\alpha, \beta$-unsaturated ketones, aldehydes, esters amides, and acids was effectively achieved and that alkyl substituents at the reactive $\beta$-centre can be accommodated. Similarly, cyclic enones undergo efficient Se-addition and the corresponding adducts were isolated in moderate to good yield. Vinyl sulfones, $\alpha, \beta$-unsaturated nitriles, and chalcones are not compatible with these reaction conditions. A recycling experiment demonstrated that the unreacted $\mathrm{Zn} / \mathrm{HCl}$ reducing system can be effectively reused for seven reaction cycles (91\% conversion yield at the $7^{\circ}$ recycling rounds).
\end{abstract}

Keywords: zinc; selenium; nucleophilic addition; seleno-Michael reaction; conjugate addition; reduction

\section{Introduction}

Organoselenium derivatives are widely utilized in the area of organic chemistry, this is due to their great versatility. The introduction of an organoselenium moiety can be easily obtained starting from diselenides that can be readily converted into electrophilic, nucleophilic, or radical species through oxidative, reductive, or homolytic cleavage of the selenium-selenium bond [1-9]. Researchers have taken advantage of this chemistry to synthesize a range of different bioactive compounds incorporating selenium [10-12]. Some selenium-containing molecules can behave as antioxidants, enzyme mimics and inhibitors, immunomodulators, cytoprotectors, antitumoral, anti-inflammatory, antihypertensive, and anti-infective agents [13-16]. Additionally, we have reported on the immunomodulatory and cytotoxic properties of selenium-containing compounds and their activity as inhibitors of several different enzymes and proteins, such as glutathione transferase (GSTp) and NCp7, which indicate interesting potential applications in anticancer and anti-HIV chemotherapy [17,18].

Nucleophilic selenolates are often generated in situ by reduction of the selenium-selenium bond in diselenides, or by the insertion of elemental selenium into organometallic species, such as Grignard reagents or organolithium derivatives [19-21]. The main drawbacks of these procedures are the use 
of inert conditions and the instability of the desired selenolates, which can rapidly oxidize to the corresponding diselenides. A variety of low-valent metals have been used for reductive cleavage of the Se-Se bond: Cd(0) [22], La(0) [23], In(0) [24], In(I) [25], Sm(0) [26,27], Sm(II) [28], Sn(0) [29], Yb(II) [30], $\mathrm{Cu}(\mathrm{II}) / \mathrm{Sn}$ (II) [31]. In addition, several different reducing agents, such as: $\mathrm{NaBH}_{4}$ [32], $\mathrm{LiAlH}_{4}$ [33], $\mathrm{LiEt}_{3} \mathrm{BH}$ [34], DIBAL [35], $\mathrm{NaB}(\mathrm{OMe})_{3} \mathrm{H}$ [36], $\mathrm{H}_{3} \mathrm{PO}_{2}$ [37], $\mathrm{N}_{2} \mathrm{H}_{4}$ [38], or Rongalite have all been used to good effect [39].

In order to obtain nucleophilic selenium species, we became interested in the applicability of zinc. The use of this metal in the S-S and Se-Se bond cleavages was already described, in combination with Lewis acids, such as aluminum chloride $\left(\mathrm{AlCl}_{3}\right)$ [40,41], zirconium tetrachloride $\left(\mathrm{ZrCl}_{4}\right)$ [42], $\mathrm{RuCl}_{3}$ [43] and $\mathrm{TiCl}_{4}$ [44], or simply basic [45] or acidic conditions [46]. The zinc insertion into Se-Halogen bond leading to the umpolung of the selenium atom and the formation of the first class of bench stable zinc selenolates, was deeply investigated, with a broad synthetic applicability [47-55]. Previously, it has been reported that this diselenide zinc-mediated reduction can be successfully coupled with chemistry aimed at derivatizing the sensitive, in situ formed selenol [56]. For instance, various epoxides [56], aziridines [57], alkyl and acyl halides [56,58] can engage in nucleophilic substitution processes and generate the corresponding organoselenide products in good to excellent yields (Scheme 1). A feature of this approach is that using a biphasic system $\left(\mathrm{Et}_{2} \mathrm{O} / \mathrm{HCl}(\mathrm{aq})\right)$, the product partitions into the organic phase, facilitating the separation and the reuse of the unreacted zinc, as well as of the aqueous acidic medium. Indeed, often a simple solvent removal leads to the isolation of Se-derivatives without the requirement for additional purification. This method proved to be the best alternative to reduce S-S and Se-Se bonds of some non-natural peptides, as recently demonstrated by Flemer [59,60].

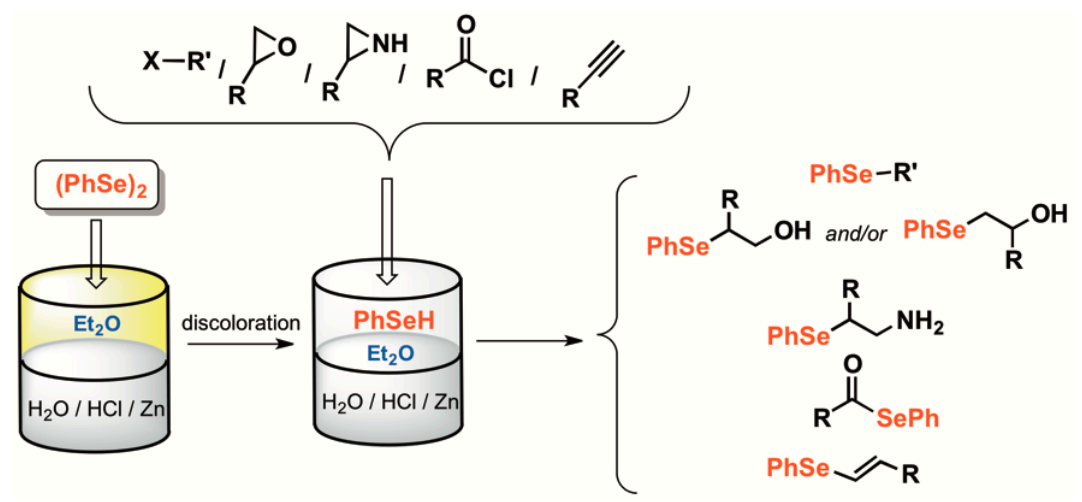

Scheme 1. One-pot zinc-mediated biphasic diselenide reduction-selenylation reaction. $1^{\text {st }}$ step: diselenide reduction evidenced by discoloration; $2^{\text {nd }}$ step selenylation (substitution and addition reactions).

More recently, we have demonstrated that the soft-selenium-based nucleophile can efficiently add to a range of alkynes [61] and we collected some of these data in a recently published review article [62]. As an extension of these studies, in this current work, we report that this in situ formed a nucleophilic selenenylating mixture that can efficiently react with a range of Michael acceptors (Scheme 2). 


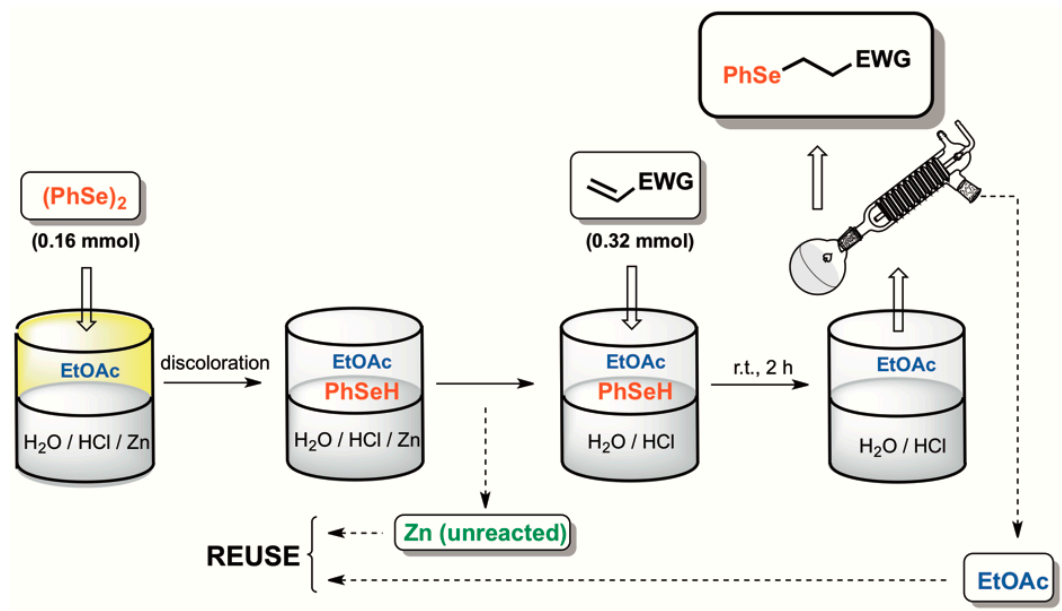

Scheme 2. One-pot zinc-mediated biphasic diselenide reduction-Se-conjugate addition reaction.

\section{Results and Discussion}

Considering that conjugated systems, mainly aldehydes and ketones (EWG $=\mathrm{CHO}, \mathrm{COR})$ can be prone to reduction in the presence of $\mathrm{Zn} / \mathrm{HCl}$ [63], new conditions were optimized with the removal of unreacted zinc after the discoloration of the organic phase, and before the addition of the substrates. Furthermore, to improve the "greenness" of the overall procedure, the organic phase (diethyl ether) was changed to ethyl acetate, because this solvent is easier to recycle, has a lower vapor pressure, and presents a series of other aspects (in terms of health and environmental impact), which have given it a recommended ranking by the CHEM21 selection guide [64].

Initially, a range of monosubstituted $\alpha, \beta$-unsaturated alkenes presenting a single electron-withdrawing group were considered. As precedingly reported [56,58], the nucleophilic selenenylating mixture arises from the reduction of the diselenide through the oxidative insertion of zinc into the Se-Se bond affording the in situ formation of a selenolate [PhSeZnSePh] that, in the acidic biphasic system, is in equilibrium with the corresponding selenol. This process takes roughly $20 \mathrm{~min}$, and experimentally the reduction progress can be visually determined by the loss of the yellow coloration in the organic phase, caused by diphenyl diselenide. The mixture was then decanted in order to remove residual unreacted zinc (used in excess) and the desired alkene was added. Following this protocol, a range of differently substituted alkenes underwent efficient conjugate addition and the adducts were isolated in moderate to good yield after stirring for $2 \mathrm{~h}$ (Table 1 ).

As shown in Table 1, Entry 1, methyl vinyl ketone 2 gave the adduct 11 in excellent yield. Similarly, acrolein 3, trans-but-2-enal 4, and trans-pent-2-enal 5 gave the corresponding phenylselenide adducts 12-14 in moderate to good yields (Table 1, Entries 2-4). The low yield in the case of 15 was primarily due to the limited stability of this Se-adduct during purification using silica-gel chromatography and not to a low conversion of the starting material. Next, we turned our attention to carboxylic acids and their derivatives. Methyl acrylate 7 and acrylic acid $\mathbf{8}$ gave ester $\mathbf{1 6}$ and acid $\mathbf{1 7}$ in good yields (Table 1, Entries 6 and 7). In the case of unsaturated amide 9 (Table 1, Entry 8), a low yield of Se-adduct 18 was isolated presumably due to poor conversion stemming from the reduced electrophilicity of the Michael-acceptor. Finally, under the conditions developed, pulegone $\mathbf{1 0}$ gave the adduct 19 in excellent yield as a mixture of diastereomers at the new chiral center (Table 1, Entry 9). Less electron-poor alkenes, such as phenyl vinyl sulfone, acrylonitrile, and chalcones did not prove to be suitable substrates and no conversions were observed under the conditions optimized for substrates $\mathbf{2}-\mathbf{1 0}$. 
Table 1. Telescoped diselenide reduction-conjugate addition to $\alpha, \beta$-unsaturated carbonyl derivatives $\mathbf{2}-\mathbf{1 0}$.

Entry

a Phenyl vinyl sulfone, acrylonitrile, and chalcones did not afford the corresponding target compound. ${ }^{\mathrm{b}}$ Quoted for analytically pure material, obtained either directly, or following purification by flash column chromatography. ${ }^{c}$ Obtained as an undetermined mixture of diastereomers (62:38) determined by the ${ }^{1} \mathrm{H}$-NMR of the crude integrating the doublets of the methyl group at $1.02 \mathrm{ppm}$ for the major isomer and 0.97 for the minor.

The reaction between diphenyl diselenide 1 and a range of cyclic enones 20-24 was next considered (Table 2). As observed in Table 2, Entry 1, using cyclopentenone 20, the adduct 25 was isolated in excellent yield. Similarly, cyclohexenone 21 and cycloheptenone 22 gave the corresponding Se-adducts 26 and 27 in comparable yields (Table 2, Entries 2 and 3). The substituent in the $\gamma$-position in cyclopentenone $\mathbf{2 3}$ was compatible with this process and product $\mathbf{2 8}$ was isolated as a 75:25 mixture of undetermined diastereomers (Table 2, Entry 4). Finally, the natural product jacaranone 24, bearing two-potential sites for nucleophilic attack, was found to form in low yield (29\%) mono-adduct 29 as a single undetermined diastereomer under the optimized conditions (Table 2, Entry 5). 
Table 2. Telescoped diselenide reduction-conjugate addition to cyclic enones 20-24.

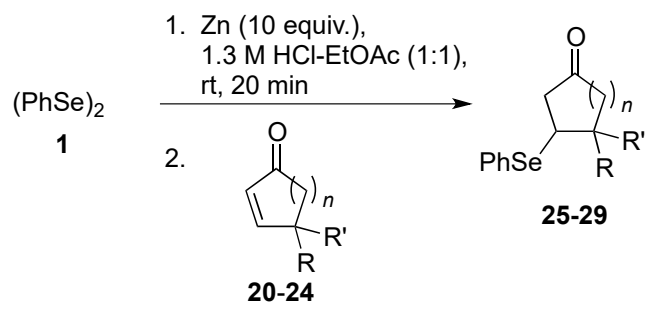

Entry Substrate

a Quoted for analytically pure material, obtained either directly or following purification by flash column chromatography. ${ }^{\mathrm{b}}$ NMR conversion of the diastereomeric mixture from which the major isomer was isolated in $62 \%$ yield after flash chromatography. Even if the attempts to clarify the relative configuration by NOE experiments failed and we were not able to obtain crystals suitable for X-ray analysis, in accordance with similar sulphur derivatives reported by some of us, we can assume a trans-geometry between substituents in C-3 and C-4 [65,66]. ${ }^{\mathrm{c}}$ Obtained as a single undetermined diastereomer.

Finally, the possibility of using alternative diselenides in the reaction with enones was considered. As shown in Table 3, both 1,2-bis(3-phenylpropyl)diselenide 30 and N,O-protected selenocystine 31 proved to generate the corresponding adducts in moderate to good yields.

As shown in Table 3, Entries 1-2, Se-adducts 34-35, obtained starting from 1,2-bis(3-phenylpropyl)diselenide 30, were isolated in good yields whereas the reactivity of the nucleophilic selenenylating mixture prepared starting from the $\mathrm{N}, \mathrm{O}$-protected selenocystine $\mathbf{3 1}$ is appreciably reduced affording the target compounds 35,36 , and 37 only in moderate yields (Entries 3,4 , and 5). Nevertheless, despite the reduced reactivity, it is worth mentioning that in these latter cases the Boc protecting group was not unduly affected by the acidic media. In the cases in which the conjugate addition of the organoselenium moiety generates a new chiral center in the presence of a preformed one in the substrate and or in the reagent (Entries 2, 4, and 5), a moderated stereoselectivity was obtained. In these cases, the reaction afforded a mixture of diastereomers from which, only in one case, was it possible to isolate the major one as a stereochemically undetermined product 34 . In the 
other two cases, probably due to their high polarity, it was not possible to separate the diastereomers 36 and 37 by flash chromatography (Table 3, Entries 4-6, respectively).

Table 3. Reaction of 1,2-bis(3-phenylpropyl)diselenide $\mathbf{3 0}$ and protected selenocystine $\mathbf{3 1}$ with enones.

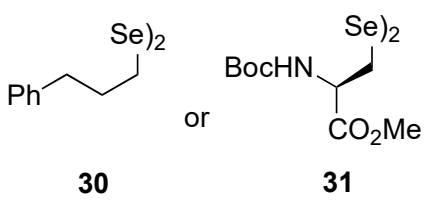

1. Zn (10 equiv.),

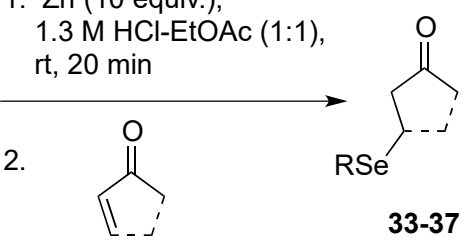

$2,21,23,24,32$

Entry

a Quoted for analytically pure material, obtained either directly or following purification by flash column chromatography. ${ }^{\mathrm{b}}$ NMR conversion of the diastereomeric mixture from which the major isomer was isolated in $49 \%$ yield after flash chromatography. In analogy with $\mathbf{2 8}$, we can assume a trans-geometry between substituents in C-3 and C-4 $[65,66] .{ }^{c}$ Obtained as an inseparable and undetermined mixture of diastereomers determined by the ${ }^{1} \mathrm{H}-\mathrm{NMR}$ of the crude.

The recyclability of the biphasic medium and of the unreacted zinc was investigated in the reaction of diphenyl diselenide 1 with cyclohexanone 21 (in a $0.04 \mathrm{M}$ solution of $\mathrm{HCl}_{10 \% v / v / E t O A c)}$ as a general model (Scheme 3). After the reaction, the superior organic phase containing the adduct 26 was separated, and part of the organic solvent was recovered by distillation. The hydrochloric aqueous solution and the unreacted zinc were reused for a subsequent cycle, by the addition of fresh EtOAc, PhSeSePh 1, and after discoloration, a new amount of cyclohexanone 21 was added. As shown in Figure 1, the conversion for the first five cycles (evaluated by ${ }^{1} \mathrm{H}-\mathrm{NMR}$ spectroscopy) was found to be quantitative and it only decreased, slightly, following the $6^{\text {th }}$ and $7^{\text {th }}$ cycles. 


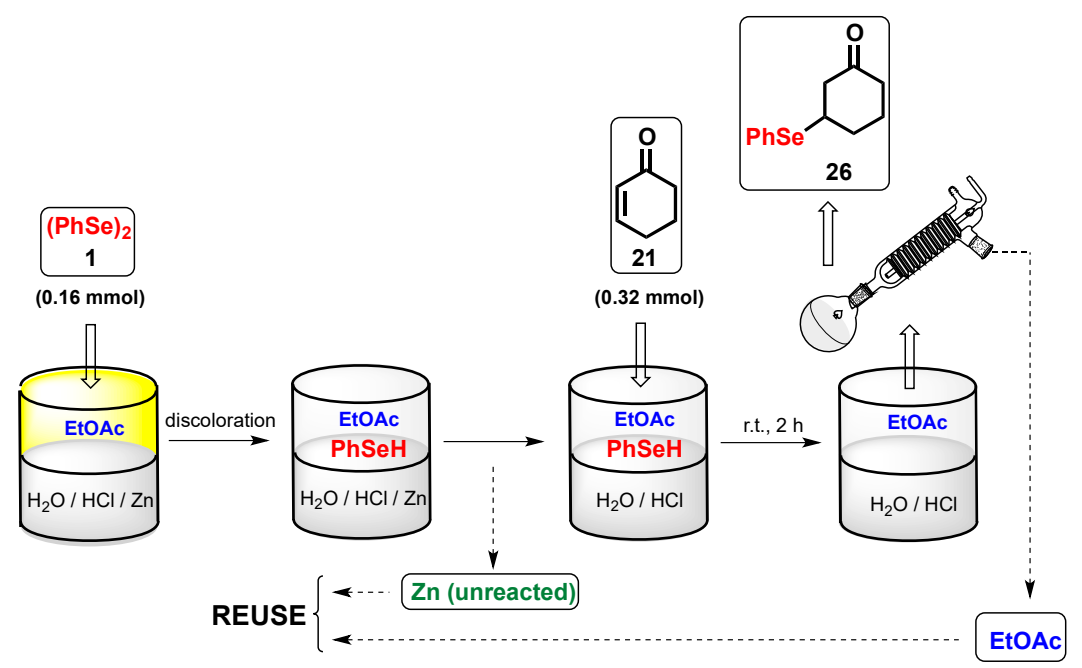

Scheme 3. Reuse of the aqueous phase in the Se-conjugate addition of diphenyl diselenide $\mathbf{1}$ to cyclohexenone 21 .

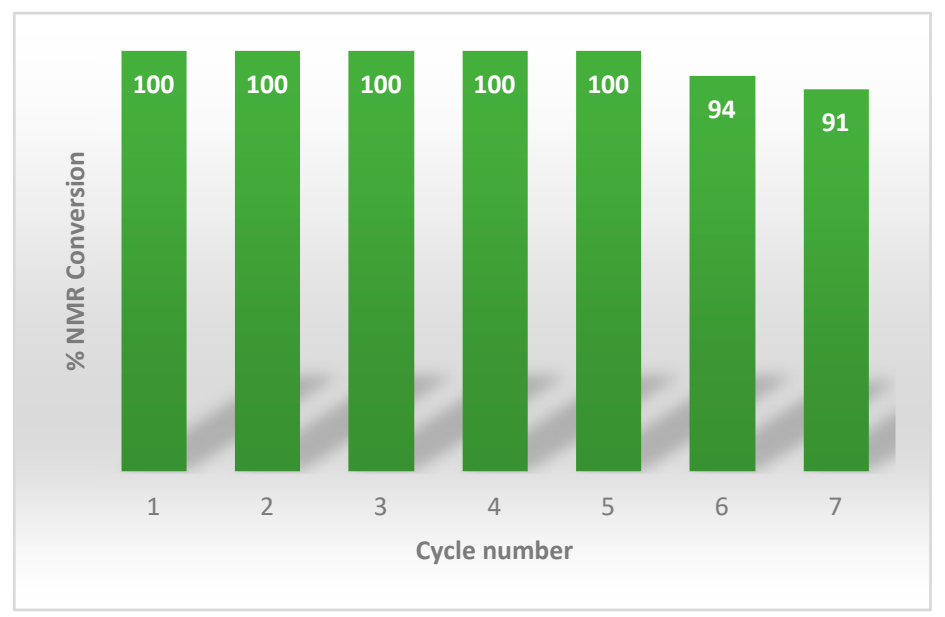

Figure 1. NMR conversion in the first seven reuses of the aqueous phase in the Se-conjugate addition of diphenyl diselenide $\mathbf{1}$ to cyclohexenone 21.

\section{Materials and Methods}

Reactions were conducted in closed vials $(6 \mathrm{~mL})$ and were stirred with a Teflon-coated magnetic stirring bar. Solvents and reagents were used as received. The analytical thin layer chromatography (TLC) was performed on silica gel 60 F254 precoated aluminum foil sheets (Merck, Darmstadt, Germany) and visualized by UV irradiation (Spectroline ${ }^{\circledR}$ UV light, Sigma-Aldrich, St Louis, Missouri, USA) or by use of a $\mathrm{KMnO}_{4}$ stain (Merck, Darmstadt, Germany) Silica gel Kiesinger 60 (70-230 mesh) was used for flash column chromatography. NMR spectroscopic (Bruker, Fällanden, Switzerland) experiments were obtained at $25^{\circ} \mathrm{C}$ on Bruker DPX spectrometers operating at the specified frequencies. ${ }^{1} \mathrm{H}$ and ${ }^{13} \mathrm{C}$ chemical shifts $(\delta)$ are reported in parts per million (ppm) and they are relative to TMS $0.0 \mathrm{ppm}$ and/or the solvent peak of $\mathrm{CDCl}_{3}$ at $\delta 7.26$ and $\delta 77.00 \mathrm{ppm}$ in ${ }^{1} \mathrm{H}$ and ${ }^{13} \mathrm{C}$ NMR spectra, respectively. Data are reported as follows: Chemical shift (multiplicity, coupling constants, number of hydrogen atoms, where applicable, and assignment where possible). Abbreviations are as follows: $\mathrm{S}$ (singlet), d (doublet), $\mathrm{t}$ (triplet), q (quartet), $\mathrm{p}$ (pentet), dd (doublet of doublet), ddd (doublet of doublet of doublet), dddd (doublet of doublet of doublet of doublet), dt (doublet of triplet), ddt (doublet of doublet of triplet), $\mathrm{tt}$ (triplet of triplet), $\mathrm{m}$ (multiplet), and bs (broad signal). Coupling constants $(J)$ are quoted in Hertz $(\mathrm{Hz})$ to the nearest $0.1 \mathrm{~Hz}$. High resolution mass spectra were carried out on a VG analytical 70-E mass spectrometer (VG Analytical Ltd., Manchester, UK) under an 
electrospray ionization condition (ESI). IR spectra were recorded on a Bruker Alpha FTIR spectrometer (Billerica, MA, USA). Optical rotation measurements were recorded using a Perkin-Elmer Model 343 polarimeter at $589 \mathrm{~nm}$ (Perkin Elmer's, Waltham, MA, USA) and are given in units of $10^{-1} \mathrm{degcm}^{2} \mathrm{~g}^{-1}$. Melting points are uncorrected and were recorded using a Gallenkamp electrothermal melting point apparatus (Cole-Parmer Ltd., Staffordshire, UK). Alkenes 2-10 and 20-22 are commercially available and were used without further purification; alkenes 23 and $\mathbf{2 4}$ (with OTBS and NHBoc substituents) were synthesized as described $[67,68]$. Jacaranone 25 was prepared by oxidation of the methyl 4-hydroxyphenylacetic acid.

Diphenyl diselenide $\mathbf{1}$ is commercially available, whereas diselenide $\mathbf{3 2}$ was prepared according to the procedure reported in the literature [69]. Selenocystine is commercially available and it was $N$ - and O-protected, according to the procedure reported in the literature [70] in order to obtain compound 33.

\section{General Procedure for the Se-Michael-Type Addition}

Diselenides (1, 32, and 33) (0.16 mmol) were introduced to a biphasic system composed of EtOAc $(2 \mathrm{~mL})$ and $\mathrm{HCl}(10 \% v / v, 2 \mathrm{~mL})$. Then, $1.6 \mathrm{mmol}$ (10 equiv.) of zinc powder (or turnings) were added. The vial was closed and the mixture was vigorously stirred (approx. $800 \mathrm{rpm}$ ) at room temperature until the discoloration of the organic layer (approx. $20 \mathrm{~min}$ ). After that, zinc was removed and the olefin $(0.32 \mathrm{mmol})$ was added to the liquid. The reaction was stirred at room temperature for an additional $2 \mathrm{~h}$. The ethyl acetate was separated and the resultant aqueous phase extracted with EtOAc $(3 \times 2 \mathrm{~mL})$. The organic layers were combined, washed with brine, dried over $\mathrm{Na}_{2} \mathrm{SO}_{4}$, filtered, and the solvent was removed under reduced pressure.

In the recycling, experiment diselenide $1(0.16 \mathrm{mmol})$ was introduced to a biphasic system composed of EtOAc $(4 \mathrm{~mL})$ and $\mathrm{HCl}(10 \% v / v, 4 \mathrm{~mL})$. Then, $1.6 \mathrm{mmol}$ (10 equiv.) of zinc turnings were added. The vial was closed and the mixture was vigorously stirred (approx. $800 \mathrm{rpm}$ ) at room temperature until the discoloration of the organic layer (approx. $20 \mathrm{~min}$ ). After that, zinc was removed and recovered and $0.32 \mathrm{mmol}$ of $\mathbf{2 1}$ was added to the liquid. The reaction was stirred at room temperature for an additional $2 \mathrm{~h}$. The ethyl acetate was separated from the aqueous layer that was recovered. The organic phase was distilled and partially recovered to obtain a crude that was analyzed by proton NMR for the conversion yield. Recovered acidic water, EtOAc, and unreacted zinc mixed with small amounts of fresh solvents to reach the original volumes $(4+4 \mathrm{~mL})$ were reused for seven subsequent cycles.

4-(Phenylselanyl)butan-2-one (11) [71]: Isolated as a yellow oil in 91\% yield (0.066 g) without purification. ${ }^{1} \mathrm{H}$ NMR (200 MHz, $\left.\mathrm{CDCl}_{3}\right) \delta: 7.60-7.45$ (m, $\left.2 \mathrm{H}, \mathrm{CH}\right), 7.30-7.20(\mathrm{~m}, 3 \mathrm{H}, \mathrm{CH}), 3.02(\mathrm{t}, J=6.7 \mathrm{~Hz}, 2 \mathrm{H}$, $\left.\mathrm{CH}_{2}\right), 2.80\left(\mathrm{t}, J=6.7 \mathrm{~Hz}, 2 \mathrm{H}, \mathrm{CH}_{2}\right), 2.18\left(\mathrm{~s}, 3 \mathrm{H}, \mathrm{CH}_{3}\right) \mathrm{ppm} ;{ }^{13} \mathrm{C} \mathrm{NMR}\left(50.31 \mathrm{MHz}, \mathrm{CDCl}_{3}\right) \delta=207.1$, 132.7, 129.6, 129.1, 127.0, 44.0, 29.9, 20.4 ppm.

3-(Phenylselanyl)propanal (12) [72]: Isolated as a yellow oil in $44 \%$ yield (0.030 g) after flash column chromatography, eluent cyclohexane/ethyl acetate (9:1). ${ }^{1} \mathrm{H} \mathrm{NMR}\left(500 \mathrm{MHz}, \mathrm{CDCl}_{3}\right) \delta: 9.74$ (bs, $1 \mathrm{H}$, $\mathrm{CH}), 7.51-7.48(\mathrm{~m}, 2 \mathrm{H}, \mathrm{CH}), 7.29-7.25(\mathrm{~m}, 3 \mathrm{H}, \mathrm{CH}), 3.09$ (t, $\left.2 \mathrm{H}, J=7.1 \mathrm{~Hz}, \mathrm{CH}_{2}\right), 2.85$ (dt, $2 \mathrm{H}$, $J=0.9$ and $\left.7.1 \mathrm{~Hz}, \mathrm{CH}_{2}\right) \mathrm{ppm} ;{ }^{13} \mathrm{C}-\mathrm{NMR}\left(125.77 \mathrm{MHz}, \mathrm{CDCl}_{3}\right) \delta=200.6,133.3,129.2,129.1,127.4,44.2$, 18.9 ppm. 
3-(Phenylselanyl)butanal (13) [73]: Isolated as a yellow oil in 70\% yield (0.051 g) after flash column chromatography, eluent petroleum ether/ethyl acetate (95:5). ${ }^{1} \mathrm{H}$ NMR $\left(200 \mathrm{MHz}, \mathrm{CDCl}_{3}\right) \delta=9.67-9.66$ (m, 1 H, CH), 7.60-7.45 (m, $2 \mathrm{H}, \mathrm{CH}), 7.30-7.20(\mathrm{~m}, 3 \mathrm{H}, \mathrm{CH}), 3.65$ (sextet, $J=7.0 \mathrm{~Hz}, 1 \mathrm{H}, \mathrm{CH}), 2.73$ (ddd, $J=1.8,7.0$, and $\left.13.5 \mathrm{~Hz}, 1 \mathrm{H}, \mathrm{CH}_{2}\right), 2.63\left(\mathrm{ddd}, J=1.7,7.0\right.$, and $\left.13.5 \mathrm{~Hz}, 1 \mathrm{H}, \mathrm{CH}_{2}\right), 1.39(\mathrm{~d}, J=7.0 \mathrm{~Hz}, 3$ $\left.\mathrm{H}, \mathrm{CH}_{3}\right) \mathrm{ppm} ;{ }^{13} \mathrm{C} \mathrm{NMR}\left(50.31 \mathrm{MHz}, \mathrm{CDCl}_{3}\right) \delta=200.8,135.6,129.2,128.2,128.0,51.0,31.7,22.1 \mathrm{ppm}$.

3-(Phenylselanyl)pentanal (14) [74]: Isolated as a yellow oil in 60\% yield $(0.030 \mathrm{~g})$ after flash column chromatography, eluent petroleum ether/ethyl acetate (95:5). ${ }^{1} \mathrm{H} \mathrm{NMR}\left(200 \mathrm{MHz}, \mathrm{CDCl}_{3}\right) \delta=9.74-9.72$ (m, $1 \mathrm{H}, \mathrm{CH}), 7.60-7.45(\mathrm{~m}, 2 \mathrm{H}, \mathrm{CH}), 7.30-7.20(\mathrm{~m}, 3 \mathrm{H}, \mathrm{CH}), 3.50(\mathrm{p}, J=6.8 \mathrm{~Hz}, 1 \mathrm{H}, \mathrm{CH}), 2.78-2.71(\mathrm{~m}$, $\left.2 \mathrm{H}, \mathrm{CH}_{2}\right), 1.76-1.61\left(\mathrm{~m}, 2 \mathrm{H}, \mathrm{CH}_{2}\right), 1.10\left(\mathrm{t}, J=7.3 \mathrm{~Hz}, 3 \mathrm{H}, \mathrm{CH}_{3}\right) \mathrm{ppm} ;{ }^{13} \mathrm{C} \mathrm{NMR}\left(50.31 \mathrm{MHz}, \mathrm{CDCl}_{3}\right)$ $\delta=201.0,135.6,129.0,128.0,127.6,48.8,40.0,28.4,12.3 \mathrm{ppm}$.

3-Methyl-3-(phenylselanyl)butanal (15) [74]: Isolated as a yellow oil in $22 \%$ yield (0.017 g) due to the limited stability during silica gel column chromatography, eluent cyclohexane/ethyl acetate $(9: 1)$. ${ }^{1} \mathrm{H} \mathrm{NMR}\left(400 \mathrm{MHz}, \mathrm{CDCl}_{3}\right) \delta=9.86(\mathrm{t}, J=2.7 \mathrm{~Hz}, 1 \mathrm{H}, \mathrm{CH}), 7.67-7.55(\mathrm{~m}, 2 \mathrm{H}, \mathrm{CH}), 7.41-7.29(\mathrm{~m}, 3 \mathrm{H}$, $\mathrm{CH}), 2.55\left(\mathrm{~d}, J=2.7 \mathrm{~Hz}, 2 \mathrm{H}, \mathrm{CH}_{2}\right), 1.51\left(\mathrm{~s}, 6 \mathrm{H}, \mathrm{CH}_{3}\right) \mathrm{ppm} .{ }^{13} \mathrm{C} \mathrm{NMR}\left(100 \mathrm{MHz}, \mathrm{CDCl}_{3}\right) \delta=201.8$, $138.3,129.1,129.0,126.9,55.1,41.9,30.0 \mathrm{ppm}$.

Methyl 3-(phenylselanyl)propanoate (16) [44]: Isolated as a yellow oil in 79\% yield $(0.097 \mathrm{~g})$ as pure compound without purification. ${ }^{1} \mathrm{H}$ NMR $\left(200 \mathrm{MHz}, \mathrm{CDCl}_{3}\right) \delta=7.60-7.45(\mathrm{~m}, 2 \mathrm{H}, \mathrm{CH}), 7.30-7.20(\mathrm{~m}$, $3 \mathrm{H}, \mathrm{CH}), 3.72\left(\mathrm{~s}, 3 \mathrm{H}, \mathrm{CH}_{3}\right), 3.15\left(\mathrm{t}, 2 \mathrm{H}, J=6.5 \mathrm{~Hz}, \mathrm{CH}_{2}\right), 2.74\left(\mathrm{t}, 2 \mathrm{H}, J=6.5 \mathrm{~Hz}, \mathrm{CH}_{2}\right) \mathrm{ppm} ;{ }^{13} \mathrm{C} \mathrm{NMR}$ $\left(50.31 \mathrm{MHz}, \mathrm{CDCl}_{3}\right) \delta=172.6,133.3,131.5,129.2,127.3,51.8,35.1,21.8 \mathrm{ppm}$.

3-(Phenylselanyl)propanoic acid (17) [75]: Isolated as a yellow oil in $60 \%$ yield $(0.140 \mathrm{~g})$ and purified by crystallization from petroleum ether and ethyl acetate. ${ }^{1} \mathrm{H}$ NMR $\left(200 \mathrm{MHz}, \mathrm{CDCl}_{3}\right) \delta=7.66-7.56(\mathrm{~m}$, $2 \mathrm{H}, \mathrm{CH}), 7.36-7.25(\mathrm{~m}, 3 \mathrm{H}, \mathrm{CH}), 3.18\left(\mathrm{t}, 2 \mathrm{H}, J=7.0 \mathrm{~Hz}, \mathrm{CH}_{2}\right), 2.86\left(\mathrm{t}, 2 \mathrm{H}, J=7.0 \mathrm{~Hz}, \mathrm{CH}_{2}\right) \mathrm{ppm}$; ${ }^{13} \mathrm{C}-\mathrm{NMR}\left(\mathrm{CDCl}_{3}, 50.31 \mathrm{MHz}\right): \delta=178.6,133.3,131.3,129.1,127.3,35.0,21.5 \mathrm{ppm}$.

$\mathrm{N}, \mathrm{N}$-Dimethyl-3-(phenylselanyl)propanamide (18): Isolated as a yellow oil in $25 \%$ yield $(0.02 \mathrm{~g})$ after flash column chromatography, eluent cyclohexane/ethyl acetate (1:1). $\mathrm{R}_{f}=0.29$ (c-Hex/EtOAc 1:1); $v_{\max }=3000,2926,1642,1578,1477,1437,1397,1326,1303,1264,1189,1128,1072,1022 \mathrm{~cm}^{-1} .{ }^{1} \mathrm{H}$ NMR $\left(500 \mathrm{MHz}, \mathrm{CDCl}_{3}\right) \delta=7.60-7.45(\mathrm{~m}, 2 \mathrm{H}, \mathrm{CH}), 7.30-7.20(\mathrm{~m}, 3 \mathrm{H}, \mathrm{CH}), 3.18\left(\mathrm{t}, 2 \mathrm{H}, J=7.6 \mathrm{~Hz}, \mathrm{CH}_{2}\right)$, $2.94\left(\mathrm{~s}, 3 \mathrm{H}, \mathrm{CH}_{3}\right), 2.92\left(\mathrm{~s}, 3 \mathrm{H}, \mathrm{CH}_{3}\right), 2.73\left(\mathrm{t}, 2 \mathrm{H}, J=7.6 \mathrm{~Hz}, \mathrm{CH}_{2}\right) \mathrm{ppm} ;{ }^{13} \mathrm{C} \mathrm{NMR}\left(125.77 \mathrm{MHz}, \mathrm{CDCl}_{3}\right)$ $\delta=171.4,132.6,130.1,129.0,126.9,37.0,35.4,34.2,22.4$ ppm. HRMS $\left(\mathrm{ESI}^{+}\right) \mathrm{C}_{11} \mathrm{H}_{15} \mathrm{NONaSe}\left(\mathrm{MNa}^{+}\right)$ calcd: 280.0217 ; found: 280.0230 .

(R)-5-Methyl-2(R/S)-(2-(phenylselanyl)propan-2-yl)cyclohexanone (19): Isolated as a yellow oil and a mixture of two isomers $(62 / 38)$ in $95 \%$ yield $(0.031 \mathrm{~g})$ after flash column chromatography, eluent petroleum ether/DCM 20:80. $v_{\max }=3070,3056,2954,2925,2869,1708,1576,1474,1455,1437,1379,1362,1285$, 1208, 1117, 1088, 1046, $1021 \mathrm{~cm}^{-1}$. For ${ }^{1} \mathrm{H}$ NMR $\left(400 \mathrm{MHz}, \mathrm{CDCl}_{3}\right)$ and ${ }^{13} \mathrm{C} \mathrm{NMR}\left(100 \mathrm{MHz}, \mathrm{CDCl}_{3}\right)$ of the mixture see Supplementary Materials. HRMS $\left(\mathrm{ESI}^{+}\right) \mathrm{C}_{16} \mathrm{H}_{22} \mathrm{ONaSe}\left(\mathrm{MNa}^{+}\right)$calcd: 333.0735; found: 333.0734 .

3-(Phenylselanyl)cyclopentanone (25) [76]: Isolated as a yellow oil in $93 \%$ yield $(0.072 \mathrm{~g})$ without purification. ${ }^{1} \mathrm{H}$ NMR $\left(200 \mathrm{MHz}, \mathrm{CDCl}_{3}\right) \delta=7.70-7.50(\mathrm{~m}, 2 \mathrm{H}, \mathrm{CH}), 7.30-7.20(\mathrm{~m}, 3 \mathrm{H}, \mathrm{CH}), 3.89(\mathrm{~m}$, $1 \mathrm{H}, \mathrm{CH}), 2.70\left(\mathrm{dd}, J=7.3\right.$ and $\left.17.8 \mathrm{~Hz}, 1 \mathrm{H}, \mathrm{CH}_{2}\right), 2.50-1.75\left(\mathrm{~m}, 5 \mathrm{H}, \mathrm{CH}_{2}\right) \mathrm{ppm} ;{ }^{13} \mathrm{C} \mathrm{NMR}(50.31 \mathrm{MHz}$, $\left.\mathrm{CDCl}_{3}\right) \delta=216.9,134.8,129.1,128.3,128.0,45.6,37.4,37.2,30.0 \mathrm{ppm}$.

3-(Phenylselanyl)cyclohexanone (26) [71]: Isolated as a yellow oil in $88 \%$ yield $(0.071 \mathrm{~g})$ without purification. ${ }^{1} \mathrm{H}$ NMR $\left(200 \mathrm{MHz}, \mathrm{CDCl}_{3}\right) \delta=7.70-7.50(\mathrm{~m}, 2 \mathrm{H}, \mathrm{CH}), 7.30-7.20(\mathrm{~m}, 3 \mathrm{H}, \mathrm{CH}), 3.45(\mathrm{tt}, J=4.4$ and $10.5 \mathrm{~Hz}, 1 \mathrm{H}, \mathrm{CH}), 2.74\left(\mathrm{ddt}, J=4.4,13.7\right.$ and $\left.1.5 \mathrm{~Hz}, 1 \mathrm{H}, \mathrm{CH}_{2}\right), 2.40(\mathrm{dd}, J=10.5$ and $13.7 \mathrm{~Hz}, 1 \mathrm{H}$, $\left.\mathrm{CH}_{2}\right), 2.36-2.06\left(\mathrm{~m}, 4 \mathrm{H}, \mathrm{CH}_{2}\right), 1.87-1.51\left(\mathrm{~m}, 2 \mathrm{H}, \mathrm{CH}_{2}\right) \mathrm{ppm} ;{ }^{13} \mathrm{C} \mathrm{NMR}\left(50.31 \mathrm{MHz}, \mathrm{CDCl}_{3}\right) \delta=208.8$, 135.6, 129.1, 128.1, 127.4, 48.6, 40.8, 40.1, 31.9, $25.1 \mathrm{ppm}$. 
3-(Phenylselanyl)cycloheptanone (27) [48]: Isolated as a yellow oil in 95\% yield (0.082 g) without purification. ${ }^{1} \mathrm{H}$ NMR $\left(200 \mathrm{MHz}, \mathrm{CDCl}_{3}\right) \delta=7.70-7.50(\mathrm{~m}, 2 \mathrm{H}, \mathrm{CH}), 7.40-7.30(\mathrm{~m}, 3 \mathrm{H}, \mathrm{CH}), 3.50$ (dddd, $J=2.8,4.0,9.6$, and $9.8 \mathrm{~Hz}, 1 \mathrm{H}, \mathrm{CH}), 2.85\left(\mathrm{ddd}, J=0.9,4.0\right.$, and $\left.14.9 \mathrm{~Hz}, 1 \mathrm{H}, \mathrm{CH}_{2}\right), 2.75(\mathrm{dd}, J=9.6$ and $\left.14.9 \mathrm{~Hz}, 1 \mathrm{H}, \mathrm{CH}_{2}\right), 2.55-2.35\left(\mathrm{~m}, 2 \mathrm{H}, \mathrm{CH}_{2}\right), 2.15-2.05\left(\mathrm{~m}, 1 \mathrm{H}, \mathrm{CH}_{2}\right) 1.86-1.44\left(\mathrm{~m}, 5 \mathrm{H}, \mathrm{CH}_{2}\right) \mathrm{ppm}$; ${ }^{13} \mathrm{C}$ NMR $\left(50.31 \mathrm{MHz}, \mathrm{CDCl}_{3}\right) \delta=211.8,135.0,129.1,128.8,128.0,50.3,43.9,38.8,37.7,29.1,23.7 \mathrm{ppm}$.

tert-Butyl ((1R,2S/R-4-oxo-2-(phenylselanyl)cyclopentyl)carbamate (28): Obtained as a mixture of diastereomers (75/25) from which the major one was isolated as a yellow oil in $62 \%$ yield $(0.05 \mathrm{~g})$ after flash column chromatography, eluent petroleum spirit/ethyl acetate (95:5). $\mathrm{R}_{f}=0.28$ (c-Hex/EtOAc 5:1); $v_{\max }=3370,3327,2976,2930,1747,1721,1675,1512,1473,1435,1391,1366,1156,1018 \mathrm{~cm}^{-1} .{ }^{1} \mathrm{H}$ NMR $\left(400 \mathrm{MHz}, \mathrm{CDCl}_{3}\right) \delta=7.70-7.50(\mathrm{~m}, 2 \mathrm{H}, \mathrm{CH}), 7.40-7.20(\mathrm{~m}, 3 \mathrm{H}, \mathrm{CH}), 4.77(\mathrm{~d}, 1 \mathrm{H}, J=5.0 \mathrm{~Hz}, \mathrm{NH})$, 4.15-4.01 (m, $1 \mathrm{H}, \mathrm{CH}), 3.52(\mathrm{q}, 1 \mathrm{H}, J=8.0 \mathrm{~Hz}, \mathrm{CH}), 2.81\left(\mathrm{dd}, 1 \mathrm{H}, J=7.6\right.$ and $\left.15.1 \mathrm{~Hz}, \mathrm{CH}_{2}\right), 2.77(\mathrm{dd}$, $1 \mathrm{H}, J=7.3$ and $\left.14.8 \mathrm{~Hz}, \mathrm{CH}_{2}\right), 2.3\left(\mathrm{dd}, 1 \mathrm{H}, J=9.1\right.$ and $\left.19.5 \mathrm{~Hz}, \mathrm{CH}_{2}\right), 2.2(\mathrm{dd}, 1 \mathrm{H}, J=8.6$ and 19.6 $\left.\mathrm{Hz}, \mathrm{CH}_{2}\right), 1.4\left(\mathrm{~s}, 9 \mathrm{H}, \mathrm{CH}_{3}\right) \mathrm{ppm} ;{ }^{13} \mathrm{C}$ NMR $\left(50.31 \mathrm{MHz}, \mathrm{CDCl}_{3}\right) \delta=212.9,155.1,135.9,129.1,128.6$, 126.4, 53.9, 45.2, 44.8, 42.2, 28.8 ppm. HRMS $\left(\mathrm{ESI}^{+}\right) \mathrm{C}_{16} \mathrm{H}_{21} \mathrm{NO}_{3} \mathrm{NaSe}\left(\mathrm{MNa}^{+}\right)$calcd: 378.0584; found: 378.0585 .

Methyl-2-(1-hydroxy-4-oxo-6-(phenylselanyl)cyclohex-2-en-1-yl)acetate (29): Isolated as a colorless oil in $29 \%$ yield $(0.031 \mathrm{~g})$ after flash column chromatography, eluent cyclohexane/ethyl acetate $(2: 1) . \mathrm{R} f=0.22$ (c-Hex/EtOAc; 2:1). $v_{\max }=3454,3056,2985,2955,2925,2852,1732,1685,1619,1577,1521,1437,1354$, $1265 \mathrm{~cm}^{-1} .{ }^{1} \mathrm{H}$ NMR $\left(500 \mathrm{MHz}, \mathrm{CDCl}_{3}\right), \delta=7.64-7.57(\mathrm{~m}, 2 \mathrm{H}, \mathrm{CH}), 7.36-7.28(\mathrm{~m}, 3 \mathrm{H}, \mathrm{CH}), 6.91(\mathrm{~d}, 1 \mathrm{H}$, $J=10.2 \mathrm{~Hz}, \mathrm{CH}), 6.02(\mathrm{~d}, 1 \mathrm{H}, J=10.2 \mathrm{~Hz}, \mathrm{CH}), 4.18(\mathrm{~s}, 1 \mathrm{H}, \mathrm{OH}), 3.74(\mathrm{dd}, 1 \mathrm{H}, J=4.3$ and $14.3 \mathrm{~Hz}$, $\mathrm{CH}), 3.75\left(\mathrm{~s}, 3 \mathrm{H}, \mathrm{CH}_{3}\right), 3.30(\mathrm{~d}, 1 \mathrm{H}, J=16.2 \mathrm{~Hz}, \mathrm{CH}), 3.11(\mathrm{dd}, 1 \mathrm{H}, J=10.0$ and $17.0 \mathrm{~Hz}, \mathrm{CH}), 2.89(\mathrm{dd}$, $1 \mathrm{H}, J=4.3$ and $17.0 \mathrm{~Hz}, \mathrm{CH}), 2.80(\mathrm{~d}, 1 \mathrm{H}, J=16.2 \mathrm{~Hz}, \mathrm{CH}) \mathrm{ppm} ;{ }^{13} \mathrm{C} \mathrm{NMR}\left(125.77 \mathrm{MHz}, \mathrm{CDCl}_{3}\right)$ : $196.8,171.9,149.3,135.2,129.4,129.1,128.3,128.2,70.0,52.22,(52.24), 50.7,42.6,42.5$ ppm. HRMS $\left(\mathrm{ESI}^{+}\right)$ $\mathrm{C}_{15} \mathrm{H}_{16} \mathrm{O}_{4} \mathrm{NaSe}\left(\mathrm{MNa}^{+}\right)$calcd: 363.0111; found: 363.0098 .

3-((3-Phenylpropyl)selanyl)cyclohexanone (33): Isolated as a yellow oil in $65 \%$ yield $(0.044 \mathrm{~g})$ and purified by flash column chromatography, eluent cyclohexane/ethyl acetate (9:1). $R_{f}=0.28$ (c-Hex/EtOAc 9:1); $v_{\max }=3026,2928,2858,2362,1714,1602,1495,1454,1274,1122,1030 \mathrm{~cm}^{-1} .{ }^{1} \mathrm{H} \mathrm{NMR}\left(400 \mathrm{MHz}, \mathrm{CDCl}_{3}\right)$ $\delta=7.28-7.25(\mathrm{~m}, 2 \mathrm{H}, \mathrm{CH}), 7.19-7.15(\mathrm{~m}, 3 \mathrm{H}, \mathrm{CH}), 3.18(\mathrm{tt}, 1 \mathrm{H}, J=3.9$ and $10.5 \mathrm{~Hz}, \mathrm{CH}), 2.76(\mathrm{ddt}, 1 \mathrm{H}$, $J=1.6,4.5$ and $\left.14.2 \mathrm{~Hz}, \mathrm{CH}_{2}\right), 2.70\left(\mathrm{t}, J=7.4 \mathrm{~Hz}, 2 \mathrm{H}, \mathrm{CH}_{2}\right), 2.60\left(\mathrm{t}, 2 \mathrm{H}, J=7.4 \mathrm{~Hz}, \mathrm{CH}_{2}\right), 2.47(\mathrm{ddd}$, $1 \mathrm{H}, J=1.1,10.9$, and $\left.14.2 \mathrm{~Hz}, \mathrm{CH}_{2}\right), 2.39-2.26\left(\mathrm{~m}, 2 \mathrm{H}, \mathrm{CH}_{2}\right), 2.19-2.06\left(\mathrm{~m}, 2 \mathrm{H}, \mathrm{CH}_{2}\right), 1.97(\mathrm{p}, 2 \mathrm{H}$, $\left.J=7.6 \mathrm{~Hz}, \mathrm{CH}_{2}\right), 1.83-1.64\left(\mathrm{~m}, 2 \mathrm{H}, \mathrm{CH}_{2}\right) \mathrm{ppm} ;{ }^{13} \mathrm{C} \mathrm{NMR}\left(100 \mathrm{MHz}, \mathrm{CDCl}_{3}\right) \delta=208.9,141.3,128.4$, 128.3, 125.9, 49.2, 40.9, 35.9, 35.8, 32.5, 32.4, 25.4, 22.5 ppm. HRMS $\left(\mathrm{ESI}^{+}\right) \mathrm{C}_{15} \mathrm{H}_{20} \mathrm{ONaSe}\left(\mathrm{MNa}^{+}\right)$calcd: 319.0577; found: 319.0568 .

(3S,4S/R)-3-((tert-Butyldimethylsilyl)oxy)-4-((3-phenylpropyl)selanyl)cyclopentanone (34): Isolated as a 89/11 mixture of undetermined diastereomers from which the major one has been isolated as a yellow oil in $49 \%$ yield $(0.050 \mathrm{~g})$ by flash column chromatography, eluent cyclohexane/ethyl acetate (95:5). $R_{f}=0.32$ (c-Hex/EtOAc; 95:5); $v_{\max }=3085,3062,3026,2953,2927,2855,1748,1604,1496,1455,1253,1102,1066$, $1026 \mathrm{~cm}^{-1} .{ }^{1} \mathrm{H}$ NMR $\left(400 \mathrm{MHz}, \mathrm{CDCl}_{3}\right) \delta=7.29-7.26(\mathrm{~m}, 2 \mathrm{H}, \mathrm{CH}), 7.20-7.15(\mathrm{~m}, 3 \mathrm{H}, \mathrm{CH}), 4.41(\mathrm{dt}, 1$ $\mathrm{H}, J=2.8$ and $5.4 \mathrm{~Hz}, \mathrm{CH}), 3.45-3.39(\mathrm{~m}, 1 \mathrm{H}, \mathrm{CH}), 2.92-2.85\left(\mathrm{~m}, 1 \mathrm{H}, \mathrm{CH}_{2}\right), 2.76-2.52\left(\mathrm{~m}, 5 \mathrm{H}, \mathrm{CH}_{2}\right)$, 2.23-2.11 (m, $\left.2 \mathrm{H}, \mathrm{CH}_{2}\right), 2.09-1.93\left(\mathrm{~m}, 2 \mathrm{H}, \mathrm{CH}_{2}\right), 0.85\left(\mathrm{~s}, 9 \mathrm{H}, \mathrm{CH}_{3}\right), 0.06\left(\mathrm{~s}, 3 \mathrm{H}, \mathrm{CH}_{3}\right), 0.04\left(\mathrm{~s}, 3 \mathrm{H}, \mathrm{CH}_{3}\right)$ ppm; ${ }^{13} \mathrm{C} \mathrm{NMR}\left(100 \mathrm{MHz}, \mathrm{CDCl}_{3}\right) \delta=215.0,128.4,128.3,126.0,125.91,75.2,46.1,43.1,41.0,35.8,31.9$, 25.6, 23.7, $-4.7,-4.8$ ppm. HRMS $\left(\mathrm{ESI}^{+}\right) \mathrm{C}_{20} \mathrm{H}_{32} \mathrm{O}_{2} \mathrm{NaSeSi}\left(\mathrm{MNa}^{+}\right)$calcd: 435.1234 ; found: 435.1235 $[\alpha] \mathrm{D}=-17\left(\mathrm{c}=0.5, \mathrm{CHCl}_{3}\right)$.

(2R)-Methyl 2-((tert-butoxycarbonyl)amino)-3-((3-oxobutyl)selanyl)propanoate (35): Isolated as a yellow oil in 30\% yield (0.021 g) after flash column chromatography, eluent cyclohexane/ethyl acetate (3:1). $\mathrm{Rf}=0.17$ (c-Hex/EtOAc; 3:1); $v_{\max }=3379,3344,2977,2953,2929,1708,1436,1365,1249,1212,1160$, 1050, $1007 \mathrm{~cm}^{-1} .{ }^{1} \mathrm{H}$ NMR $\left(600 \mathrm{MHz}, \mathrm{CDCl}_{3}\right) \delta=5.35(\mathrm{~d}, 1 \mathrm{H}, J=6.5 \mathrm{~Hz}, \mathrm{NH}), 4.59(\mathrm{~d}, 1 \mathrm{H}, J=6.9 \mathrm{~Hz}$, $\mathrm{CH}), 3.74\left(\mathrm{~s}, 3 \mathrm{H}, \mathrm{CH}_{3}\right), 3.05-2.98\left(\mathrm{~m}, 2 \mathrm{H}, \mathrm{CH}_{2}\right), 2.85-2.79\left(\mathrm{~m}, 2 \mathrm{H}, \mathrm{CH}_{2}\right), 2.74-2.70\left(\mathrm{~m}, 2 \mathrm{H}, \mathrm{CH}_{2}\right), 2.14$ 
(s, $\left.3 \mathrm{H}, \mathrm{CH}_{3}\right), 1.43\left(\mathrm{~s}, 9 \mathrm{H}, \mathrm{CH}_{3}\right)$ ppm; ${ }^{13} \mathrm{C}-\mathrm{NMR}\left(125.77 \mathrm{MHz}, \mathrm{CDCl}_{3}\right) \delta=206.7,171.5,154.9,80.0,53.5$, 52.6, 44.4, 29.9, 28.3, 26.6, 17.5 ppm. HRMS $\left(\mathrm{ESI}^{+}\right) \mathrm{C}_{13} \mathrm{H}_{23} \mathrm{NO}_{5} \mathrm{NaSe}\left(\mathrm{MNa}^{+}\right)$calcd: 376.0639; found: $376.0653[\alpha] \mathrm{D}=+19\left(\mathrm{c}=0.5, \mathrm{CHCl}_{3}\right)$.

Methyl 2-((tert-butoxycarbonyl)amino)-3-((3-oxocyclohexyl)selanyl)propanoate (36): Isolated as a yellow oil in $53 \%$ yield $(0.050 \mathrm{~g})$ as mixture of two inseparable diastereomers (66/34) after flash column chromatography, eluent cyclohexane/ethyl acetate (3:1). $\mathrm{R}_{f}=0.23$ (c-Hex/EtOAc; 3:1); $v_{\max }=3358$, 2976, 1742, 1704, 1500, 1436, 1392, 1365, 1346, 1248, 1215, 1048, $1007 \mathrm{~cm}^{-1}$. For ${ }^{1} \mathrm{H}$ NMR $(500 \mathrm{MHz}$, $\left.\mathrm{CDCl}_{3}\right)$ and ${ }^{13} \mathrm{C} \mathrm{NMR}\left(125.77 \mathrm{MHz}, \mathrm{CDCl}_{3}\right)$ of the mixture, see Supplementary Materials. HRMS $\left(\mathrm{ESI}^{+}\right)$ $\mathrm{C}_{15} \mathrm{H}_{25} \mathrm{NO}_{5} \mathrm{NaSe}\left(\mathrm{MNa}^{+}\right)$calcd: 402.0796; found: 402.0779 .

Methyl-2-((tert-butoxycarbonyl)amino)-3-(((2S)-2-((tert-butoxycarbonyl)amino)-4-oxocyclopentyl)selanyl) propanoate (37): Isolated as a white solid, mixture of diastereomers (55/45) in a 30\% yield $(0.046 \mathrm{~g})$ after recrystallization from a concentrated DCM solution which was layered with c-Hex. $\mathrm{R}_{f}=0.28$ (c-Hex/EtOAc; 5:1). m.p. $114-116^{\circ}$ C. $v_{\max }=3362,2932,1743,1677,1511,1437,1366,1317,1278,1253$, $1228,1161,1045,1017 \mathrm{~cm}^{-1}$. For ${ }^{1} \mathrm{H}$ NMR $\left(600 \mathrm{MHz}, \mathrm{CDCl}_{3}\right)$ and ${ }^{13} \mathrm{C} \mathrm{NMR}\left(150.9 \mathrm{MHz}, \mathrm{CDCl}_{3}\right)$ of the mixture, see Supplementary Materials. HRMS $\left(\mathrm{ESI}^{+}\right) \mathrm{C}_{19} \mathrm{H}_{32} \mathrm{~N}_{2} \mathrm{O}_{7} \mathrm{NaSe}\left(\mathrm{MNa}^{+}\right)$calcd: 503.1272; found: 503.1271 .

\section{Conclusions}

An efficient, fast, and safe protocol for seleno-Michael-type addition reactions has been reported. The method represents a good way to achieve the in situ reduction of diphenyl diselenide 1 using a biphasic $\mathrm{Zn}-\mathrm{EtOAc}-\mathrm{HCl}(\mathrm{aq})$ mixture. The resultant nucleophilic selenenylating mixture was shown to react with a range of Michael acceptors in order to provide the corresponding Se-adducts. Yields are often high and these were found to depend on the electrophilicity of the substrate. Alternative diselenides 32 and 33 were successfully used, affording Se-alkylated versions of protected selenocysteine.

Supplementary Materials: The following are available online at http:/www.mdpi.com/1420-3049/25/9/2018/s1, Figure of NMR spectra of all the synthesized compounds.

Author Contributions: Conceptualization, C.S., P.E., and E.J.L.; methodology, C.S., P.E., and E.J.L.; investigation, F.G.N. and B.M.; resources, C.S., P.E., and E.J.L.; data curation, C.S., P.E., and E.J.L., writing-original draft preparation, F.G.N. and B.M.; writing-review and editing, C.S., P.E., and E.J.L.; visualization, F.G.N. and B.M.; supervision, C.S., P.E., and E.J.L.; funding acquisition, C.S. and P.E. All authors have read and agreed to the published version of the manuscript.

Funding: This research received no external funding.

Acknowledgments: University of Perugia for Fondo per il sostegno della Ricerca di Base 2018, Project "Sviluppo di metodologie innovative per la sintesi efficiente di composti eterociclici, molecole drug-like e intermedi sintetici ad alto valore aggiunto" (C.S.) and "Mobilità Accordi Quadro"(B.M.); CAPES-Coordenação de Aperfeiçoamento de Pessoal de Nivel Superior-Brasil-Finance Code 001, FAPERGS (PqG 17/2551-0000987-8), CNPq and FINEP (E.J.L.); the Eramus + trainership program and University College Dublin (F.G.N.) are acknowledged for their support. Clodagh Muldowney is thanked for the synthesis of 25. This work has been undertaken under the umbrella of the Selenium Sulfur Redox and Catalysis Network (SeSRedCat).

Conflicts of Interest: The authors declare no conflict of interest.

\section{References}

1. Nicolaou, K.C.; Petasis, N.A. Selenium in Natural Products Synthesis; CIS: Philadelphia, PA, USA, 1984.

2. Paulmier, C. Selenium Reagents and Intermediates in Organic Synthesis; Pergamon: Oxford, UK, 1986.

3. Patai, S.; Rappoport, Z. The Chemistry of Organic Selenium and Tellurium Compounds; Wiley: New York, NY, USA, 1986.

4. Liotta, D. Organoselenium Chemistry; Wiley: New York, NY, USA, 1987.

5. Back, T.G. Organoselenium Chemistry: A Practical Approach; Oxford University Press: Oxford, UK, 1999.

6. Reich, H.J. Functional Group Manipulation Using Organoselenium Reagents. Acc. Chem. Res. 1979, 12, 22-30. [CrossRef]

7. Liotta, D. New Organoselenium Methodology. Acc. Chem. Res. 1984, 17, 28-34. [CrossRef] 
8. Wirth, T. Organoselenium Chemistry-Modern Developments in Organic Synthesis, Topics in Current Chemistry; Spring: Heidelberg, Germany, 2000. [CrossRef]

9. Mugesh, G.; Singh, H.B. Heteroatom-Directed Aromatic Lithiation: A Versatile Route to the Synthesis of Organochalcogen (Se, Te) Compounds. Acc. Chem. Res. 2002, 35, 226-236. [CrossRef] [PubMed]

10. Rigby, J.H.; Maharoof, U.S.M.; Mateo, M.E. Studies on the Narciclasine Alkaloids: Total Synthesis of (+)-Narciclasine and (+)-Pancratistatin. J. Am. Chem. Soc. 2000, 122, 6624-6628. [CrossRef]

11. Knapp, S.; Zhao, D. Synthesis of the Sialidase Inhibitor Siastatin B. Org. Lett. 2000, 25, 4037-4040. [CrossRef]

12. Treadwell, E.M.; Neighbors, J.D.; Wiemer, D.F. A Cascade Cyclization Approach to Schweinfurthin B. Org. Lett. 2002, 21, 3639-3642. [CrossRef]

13. Hossain, S.U.; Sharma, A.K.; Ghosh, S.; Bhattacharya, S. Synthesis and Biological Evaluation of Novel Spiro 6-methoxytetralin-1,3'-pyrrolidine Based Organoselenocyanates Against Cadmium-induced Oxidative and Hepatic Damage in Mice. Eur. J. Med. Chem. 2010, 45, 3265-3273. [CrossRef]

14. Jeong, L.S.; Choi, Y.N.; Tosh, D.K.; Choi, W.J.; Kim, H.O.; Choi, J.J. Design and Synthesis of Novel 2', 3' -dideoxy-4'-selenonucleosides as Potential Antiviral Agents. Bioorg. Med. Chem. 2008, 16, 9891-9897. [CrossRef]

15. De Souza, D.; Mariano, D.O.; Nedel, F.; Schultze, E.; Campos, V.F.; Seixas, F.; da Silva, R.S.; Munchen, T.S.; Ilha, V.; Dornelles, L.; et al. New Organochalcogen Multitarget Drug: Synthesis and Antioxidant and Antitumoral Activities of Chalcogenozidovudine Derivatives. J. Med. Chem. 2015, 58, 3329-3339. [CrossRef]

16. Pietrella, D. Antimicrobial activity of Organoselenium Compounds. In Organoselenium Chemistry: Between Synthesis and Biochemistry; Santi, C., Ed.; Bentham eBooks: Sharjah, UAE, 2014; pp. 328-344. [CrossRef]

17. Legnaioli, S.; Piroddi, M.; Tidei, C.; Santi, C.; Galli, F. Targeting the GSTP-dependent Control of Cell Kinases and Apoptosis with PhSeZnCl: A New Seleno-organic Drug. Free Radical. Biol. Med. 2012, 53, S112-S113. [CrossRef]

18. Sancineto, L.; Mariotti, A.; Bagnoli, L.; Marini, F.; Desantis, J.; Iraci, N.; Santi, C.; Pannecouque, C.; Tabarrini, O. Design and Synthesis of DiselenoBisBenzamides (DISeBAs) as Nucleocapsid Protein 7 (NCp7) Inhibitors with anti-HIV Activity. J. Med. Chem. 2015, 58, 9601-9614. [CrossRef]

19. Krief, A.; Havesi, L. Organoselenium Chemistry; Springer: Berlin/Heidelberg, Germany, 1988.

20. Krief, A. Alkylations of Sulfur- and Selenium-containing Carbanions. In Comprehensive Organometallic Chemistry; Trost, B.M., Fleming, I., Pattenden, G., Eds.; Elsevier: Amsterdam, The Netherlands, 1991; pp. 85-191.

21. Wirth, T. Selenium. In Comprehensive Organometallic Chemistry III; Crabtree, R.H., Mingos, D.M.P., Eds.; Elsevier: Amsterdam, The Netherlands, 2006; pp. 457-500.

22. Zhang, Y.; Bao, W.; Zheng, Y. Synthesis of Allyl-Type Selenides and $\alpha$-Selenoesters in Aqueous Media Promoted by Cadmium. Synth. Commun. 2000, 30, 1731-1736. [CrossRef]

23. Sonoda, N.; Okada, M.; Kuroki, T.; Watanabe, T.; Nishiyama, Y.; Nishino, T. One-Pot Synthetic Method of Unsymmetrical Diorganyl Selenides: Reaction of Diphenyl Diselenide with Alkyl Halides in the Presence of Lanthanum Metal. J. Org. Chem. 2002, 67, 8696-8698. [CrossRef]

24. Zheng, Y.; Zhang, Y.; Zhou, J.; Bao, W. A Novel Synthesis of Allyl and Propargyl Selenides in Aqueous Media Promoted by Indium. Tetrahedron Lett. 1996, 37, 9333-9334. [CrossRef]

25. Mandal, T.; Samanta, S.; Ranu, B.C. Indium(I) Iodide-Mediated Cleavage of Diphenyl Diselenide. An Efficient One-Pot Procedure for the Synthesis of Unsymmetrical Diorganyl Selenides. Org. Lett. 2003, 5, 1439-1441. [CrossRef]

26. Zheng, Y.; Zhang, Y.; Guo, H. Convenient One-Pot Synthesis of $\alpha$-Selenonitriles, $\alpha$-Selenoesters and Asymmetrical Selenides by a $\mathrm{Sm} / \mathrm{ZnCl}_{2}$ system in DMF-H ${ }_{2} \mathrm{O}$. J. Chem. Res. 2001, 160-161.

27. Guo, H.; Zhang, Y.; Zheng, Y. Synthesis of Allyl Selenides Promoted by an $\mathrm{Sm} / \mathrm{ZnCl}_{2}$ Bimetal System in the Presence of Water. Chin. J. Chem. 2001, 19, 530-532. [CrossRef]

28. Fujinami, T.; Sakai, S.; Fukuzawa, S. Samarium(II) Di-iodide Induced Synthesis of Allylic Phenyl Selenides from Allylic Acetates and Diphenyl Diselenide in the Presence of Palladium Catalyst. Chem. Lett. 1990, 927-930. [CrossRef]

29. Bao, W.; Zhang, Y.; Liao, P. A Novel Synthesis of Allyl and Prop-2-ynyl Selenides Promoted by Tin in the Presence of Water. J. Chem. Res. (S) 1998, 150-151. [CrossRef]

30. Zhang, Y.; Zheng, Y.; Li, Y.; Su, W. Facile Formation of Ytterbium Diiodide and Its Use in the Synthesis of Allyl Selenides. Chin. J. Chem. 2002, 20, 174-177. [CrossRef] 
31. Roy, S.; Kundu, A. Copper(II)/Tin(II) Reagent for Allylation, Propargylation, Alkynylation, and Benzylation of Diselenides: A Novel Bimetallic Reactivity. Organometallics 2000, 19, 105-107. [CrossRef]

32. Reddy, K.M.; Mugesh, G. Application of Dehydroalanine as a Building Block for the Synthesis of Selenocysteine-containing Peptides. RSC Adv. 2019, 9, 34-43. [CrossRef]

33. Krief, A.; Cravador, A. Nouvelles Methods de Synthèse des Méthylsélénoacétals et Cétals. C. R. Acad. Sci. Paris 1979, 289c, 267-269.

34. Katsumata, K.; Watanabe, Y.; Toru, T.; Veno, Y.; Sakakakibara, M. A Convenient Procedure for the Preparation of Organic Selenides. Synthesis 1992, 377-379. [CrossRef]

35. Miyazaki, T.; Ando, M.; Matsumura, Y.; Sakane, S.; Hattori, K.; Yamamoto, H.; Maruoka, K. Organoaluminum-promoted Beckmann Rearrangement of Oxime Sulfonates. J. Am. Chem. Soc. 1983, 105, 2831-2843. [CrossRef]

36. Berkowitz, D.B.; Pedersen, M.L. Formal $\alpha$-vinylation of Amino Acids. Use of a New Benzeneselenolate Equivalent. J. Org. Chem. 1993, 58, 6966-6975. [CrossRef]

37. Block, H.D.; Schmidt, M. Notiz zur Vereinfachten Darstellung von Alkanselenolen. Chem. Ber. 1970, 103, 3348-3349. [CrossRef]

38. Mlochowsky, J.; Syper, L. The Convenient Syntheses of Organoselenium Reagents. Synthesis 1984, 439-442. [CrossRef]

39. Dan, W.; Deng, H.; Chen, J.; Liu, M.; Ding, M.; Wu, H. A New Odorless One-pot Synthesis of Thioesters and Selenoesters Promoted by Rongalite. Tetrahedron 2010, 66, 7384-7388. [CrossRef]

40. Lakouraj, M.M.; Movassagh, B.; Fadaei, Z. Convenient Synthesis of Thiol Esters from Acyl Chlorides and Disulfides Using Zn/AlCl 3 . Monatsh. Chem. 2002, 133, 1085-1088. [CrossRef]

41. Movassagh, B.; Lakouraj, M.M.; Fadaei, Z. A Convenient One-pot Synthesis of Thiol Esters from Disulfides Using a $\mathrm{Zn} / \mathrm{AlCl}_{3}$ System. J. Chem. Res. (S) 2001, 22-23. [CrossRef]

42. Tian, F.S.; Zhu, Y.M.; Zhang, S.L.; Wang, Y.L. A Novel Method for the Synthesis of Unsymmetrical Sulfides, Thioesters and $\beta$-thioesters. J. Chem. Res. (S) 2002, 11, 582-583. [CrossRef]

43. Movassagh, B.; Tatar, A. Zn/RuCl3-Promoted Cleavage of Diselenides: An Efficient Michael Addition of Zinc Selenolates to Conjugated Alkenes in Aqueous Media. Synlett 2007, 12, 1954-1956. [CrossRef]

44. Zhou, L.-H.; Zhang, Y.-M. An Effective Synthesis of $\beta$-Selenium and $\beta$-Tellurium Carbonyl Compounds Via Reaction of Diaryldiselenides Or Diarylditellurides with $\alpha, \beta$-Unsaturated Carbonyl Compounds Induced by Low-Valent Titanium. Synth. Commun. 1999, 29, 533-540. [CrossRef]

45. Nunes, V.L.; de Oliveira, I.C.; do Rego Barros, O.S. Organylzinc Chalcogenolate Promoted Michael-Type Addition of $\alpha, \beta$-Unsaturated Carbonyl Compounds. Eur. J. Org. Chem. 2014, 1525-1530. [CrossRef]

46. Sancineto, L.; Vargas, J.P.; Monti, B.; Arca, M.; Lippolis, V.; Perin, G.; Lenardão, E.J.; Santi, C. Atom Efficient Preparation of Zinc Selenates for the Synthesis of Selenol Esters under "On Water" Conditions. Molecules 2017, 22, 953. [CrossRef]

47. Santi, C.; Santoro, S.; Battistelli, B.; Testaferri, L.; Tiecco, M. Preparation of the First Bench-Stable Phenyl Selenolate: An Interesting “On Water” Nucleophilic Reagent. Eur. J. Org. Chem. 2008, 5387-5390. [CrossRef]

48. Santoro, S.; Battistelli, B.; Testaferri, L.; Tiecco, M.; Santi, C. Vinylic Substitutions Promoted by PhSeZnCl: Synthetic and Theoretical Investigations. Eur. J. Org. Chem. 2009, 4921-4925. [CrossRef]

49. Santi, C.; Battistelli, B.; Testaferri, L.; Tiecco, M. On Water Preparation of Phenylselenoesters. Green Chem. 2012, 14, 1277-1280. [CrossRef]

50. Battistelli, B.; Testaferri, L.; Tiecco, M.; Santi, C. “On-Water” Michael-Type Addition Reactions Promoted by PhSeZnCl. Eur. J. Org. Chem. 2011, 1848-1851. [CrossRef]

51. Salman, S.; Schwab, R.; Alberto, E.E.; Vargas, J.; Dornelles, L.; Rodrigues, O.E.D.; Braga, A.L. Efficient Ring Opening of Protected and Unprotected Aziridines Promoted by Stable Zinc Selenolate in Ionic Liquid. Synlett 2011, 69-72. [CrossRef]

52. Nagasawa, T.; Shimada, N.; Torihata, M.; Kuwahara, S. Enantioselective Total Synthesis of Idesolide via $\mathrm{NaHCO}_{3}$-promoted Dimerization. Tetrahedron 2010, 66, 4965-4969. [CrossRef]

53. Jiang, H.; Pan, X.; Li, N.; Zhang, Z.; Zhu, J.; Zhu, X. Selenide-containing High Refractive Index Polymer Material with Adjustable Refractive Index and Abbe's Number. React. Funct. Polym. 2017, 111, 1-6. [CrossRef] 
54. Kim, Y.; Mulay, S.V.; Choi, M.; Yu, S.B.; Jon, S.; Churchill, D.G. Exceptional Time Response, Stability and Selectivity in Doubly-activated Phenyl Selenium-based Glutathione-selective Platform. Chem. Sci. 2015, 6, 5435-5439. [CrossRef]

55. Jardim, G.A.M.; Bozzi, I.A.O.; Oliveira, W.X.C.; Mesquita-Rodrigues, C.; Menna-Barreto, R.F.S.; Kumar, R.A.; Gravel, E.; Doris, E.; Braga, A.L.; da Silva Júnior, E.N. Copper Complexes and Carbon nanotube-copper Ferrite-catalyzed Benzenoid A-ring Selenation of Quinones: An Efficient Method for the Synthesis of Trypanocidal agents. New J. Chem. 2019, 43, 13751-13763. [CrossRef]

56. Santi, C.; Santoro, S.; Testaferri, L.; Tiecco, M. A Simple Zinc-Mediated Preparation of Selenols. Synlett 2008, 1471-1474. [CrossRef]

57. Braga, A.L.; Schwab, R.S.; Alberto, E.E.; Salman, S.M.; Vargas, J.; Azeredo, J.B. Ring Opening of Unprotected Aziridines by Zinc Selenolates in a Biphasic System. Tetrahedron Lett. 2009, 50, 2309-2311. [CrossRef]

58. Bellino, G.; Scisciani, M.; Vargas, J.P.; Sancineto, L.; Bagnoli, L.; Marini, L.; Lüdtke, D.S.; Lenardão, E.J.; Santi, C. Reaction of Acyl Chlorides with In Situ Formed Zinc Selenolates: Synthesis of Selenoesters versus Ring-Opening Reaction of Tetrahydrofuran. J. Chem. 2016, 1-8. [CrossRef]

59. Flemer, S., Jr. A Comprehensive One-Pot Synthesis of Protected Cysteine and Selenocysteine SPPS Derivatives. Prot. Pept. Lett. 2014, 21, 1257-1264.

60. Flemer, S., Jr. Fmoc-Sec(Xan)-OH: Synthesis and Utility of Fmoc Selenocysteine SPPS Derivatives with Acid-Labile Sidechain Protection. J. Pept. Sci. 2015, 21, 53-59. [CrossRef]

61. Tidei, C.; Sancineto, L.; Bagnoli, L.; Battistelli, B.; Marini, F.; Santi, C. A Recyclable Biphasic System for Stereoselective and Easily Handled Hydrochalcogenations. Eur. J. Org. Chem. 2014, 5968-5975. [CrossRef]

62. Santi, C.; Jacob, R.G.; Monti, B.; Bagnoli, L.; Sancineto, L.; Lenardão, E.J. Water and Aqueous Mixtures as Convenient Alternative Media for Organoselenium Chemistry. Molecules 2016, 21, 1482. [CrossRef] [PubMed]

63. Kuo, S.-C.; Chen, F.; Hou, D.; Kim-Meade, A.; Bernard, C.; Liu, J.; Levy, S.; Wu, G.G. A Novel Enantioselective Alkylation and Its Application to the Synthesis of an Anticancer Agent. J. Org. Chem. 2013, 68, 4984-4987. [CrossRef] [PubMed]

64. Prat, D.; Wells, A.; Hayler, J.; Sneddon, H.; McElroy, C.R.; Abou-Shehada, S.; Dunn, P.J. CHEM21 Selection Guide of Classical- and Less Classical-solvents. Green Chem. 2016, 18, 288-296. [CrossRef]

65. Bickley, J.F.; Evans, P.; Meek, A.; Morgan, B.S.; Roberts, S.M. Novel Preparation of (-)-4-Hydroxycyclohex-2-enone: Reaction of 4-hydroxycyclohex-2-enone and 4-hydroxycyclopent-2-enone with some Thiols. Tetrahedron: Asymmetry 2006, 17, 355-362. [CrossRef]

66. O’Byrne, A.; Murray, C.; Keegan, D.; Palacio, C.; Evans, P.; Morgan, B.S. The Thio-adduct Facilitated, Enzymatic Kinetic Resolution of 4-hydroxycyclopentenone and 4-hydroxycyclohexenone. Org. Biomol. Chem. 2010, 8, 539-545. [CrossRef]

67. Johnson, C.R.; Braun, M.P. A Two-Step, Three-Component Synthesis of PGE1: Utilization of $\alpha$-Iodoenones in Pd(0)-Catalyzed Cross-Couplings of Organoboranes. J. Am. Chem. Soc. 1993, 115, 11014-11015. [CrossRef]

68. Dauvergne, J.; Happe, A.M.; Jadhav, V.; Justice, D.; Matos, M.-C.; McCormack, P.J.; Pitts, M.R.; Roberts, S.M.; Singh, S.K.; Snape, T.J.; et al. Synthesis of 4-azacyclopent-2-enones and 5,5-diakyl-4-azacyclopent-2-enones. Tetrahedron 2004, 60, 2559-2567. [CrossRef]

69. Zhao, X.; Yu, Z.; Zeng, F.; Chen, J.; Wu, X.; Wu, S.; Xiao, W.-J.; Zheng, Z. Highly Efficient Route to Diselenides from the Reactions of Imines and Selenium in the Presence of Carbon Monoxide and Water. Adv. Synth. Catal. 2005, 347, 877-882. [CrossRef]

70. Liu, J.; Zheng, F.; Cheng, R.; Li, S.; Rozovsky, S.; Wang, Q.; Wang, L. Site-Specific Incorporation of Selenocysteine Using an Expanded Genetic Code and Palladium-Mediated Chemical Deprotection. J. Am. Chem. Soc. 2018, 140, 8807-8816. [CrossRef]

71. Chu, C.-M.; Gao, S.; Sastry, M.N.V.; Kuo, C.-W.; Lu, C.; Liu, J.-T.; Yao, C.-F. Ceric Ammonium Nitrate (CAN) as a Green and Highly Efficient Promoter for the 1,4-addition of Thiols and Benzeneselenol to $\alpha, \beta$-Unsaturated Ketones. Tetrahedron 2007, 63, 1863-1871. [CrossRef]

72. Pedrosa, R.; Andrés, C.; Duque-Soladana, J.P.; Rosón, C.D. Regio- and Stereoselective 6-exo-trig Radical Cyclisations onto Chiral Perhydro-1,3-benzoxazines: Synthesis of Enantiopure 3-alkylpiperidines. Tetrahedron 2000, 11, 2809-2821. [CrossRef] 
73. Sanz, X.; Vogels, C.M.; Decken, A.; Bo, C.; Westcott, T.A.; Fernandez, E. Face to Face Activation of a Phenylselenium Borane with $\alpha, \beta$-Unsaturated Carbonyl Substrates: Facile Synthesis of C-Se Bonds. Chem. Comm. 2014, 50, 8420-8423. [CrossRef] [PubMed]

74. Nishiyama, Y.; Asano, T.; Kishimoto, Y.; Itoh, K.; Ishii, Y. Selective Synthesis of 1-Alkoxy-3-phenylseleno-1-alkenes and 3-Phenylselenoalkanals by the Reaction of Diisobutylaluminum Phenylselenolate with $\alpha, \beta$-Unsaturated Acetals. Tetrahedron Lett. 1998, 39, 8685-8686. [CrossRef]

75. Bhalla, A.; Sharma, S.; Bhasin, K.K.; Bari, S.S. Convenient Preparation of Benzylseleno- and Phenylselenoalkanoic Acids: Reagents for Synthesis of Organoselenium Compounds. Synth. Commun. 2007, 37, 783-793. [CrossRef]

76. Miyashita, M.; Toshikoshi, A. Facile and Highly Efficient Conjugate Addition of Benzeneselenol to $\alpha, \beta$-Unsaturated Carbonyl Compounds. Synthesis 1980, 8, 664-666. [CrossRef]

Sample Availability: Samples of the compounds are not available from the authors.

(C) 2020 by the authors. Licensee MDPI, Basel, Switzerland. This article is an open access article distributed under the terms and conditions of the Creative Commons Attribution (CC BY) license (http://creativecommons.org/licenses/by/4.0/). 